\title{
Palaeovalleys at the basal unconformity of the Palaeoproterozoic Karrat Group, West Greenland
}

\author{
Pierpaolo Guarnieri, Camille A. Partin and Diogo Rosa
}

In the Rinkian belt of West Greenland, reworked Archaean gneisses are overlain by supracrustal successions of the Palaeoproterozoic Karrat Group, defined by Henderson \& Pulvertaft (1967) as comprising two formations: the Qeqertarssuaq Formation and the Nûkavsak Formation. The group was later extended to include the Mârmorilik Formation (Henderson \& Pulvertaft 1987) originally considered to be of Archaean age (Henderson \& Pulvertaft 1967) but later shown to be Palaeoproterozoic, resting with a depositional unconformity on Archaean gneiss (Garde 1978). Henderson \& Pulvertaft (1987) suggested that the carbonatedominated Mârmorilik Formation in the south was laterally equivalent to the siliciclastic-dominated Qeqertarssuaq Formation in the north, the two subbasins being separated by a basement topographic high.

The Karrat Group and the Archaean basement were metamorphosed and folded during the Rinkian orogeny (Henderson \& Pulvertaft 1987; Grocott \& Pulvertaft 1990). During ship- and helicopter-supported fieldwork in 2015, the Kangerluarsuk-Maarmorilik area (Fig. 1) was visited to sample the $\mathrm{Zn}-\mathrm{Pb}$-mineralised horizons found by RTZ Mining and Exploration Ltd. (Coppard et al. 1992) along the basement-cover boundary and to obtain oblique photographs of the contact that was described as faults on the Mârmorilik geological map sheet (scale 1:100 000, Henderson \& Pulvertaft 1987). The aim of this paper is to show preliminary new results on the geometry and type of unconformity between the Palaeoproterozoic Karrat Group and the underlying gneisses, and to describe a new stratigraphic unit representing here the lowermost sedimentary sequence above the unconformity. This unit is of particular relevance as it controls the distribution of the $\mathrm{Zn}-\mathrm{Pb}$ mineralisation.

\section{Palaeoproterozoic palaeovalleys as a result of unconformity}

One of the best localities to characterise the basal unconformity of the Palaeoproterozoic Karrat Group is along a cliff face of Qaarsukassak at the head of Kangerluarsuk (Fig. 1). The more than $1800 \mathrm{~m}$ high cliff face exposes Archaean basement rocks (Umanak gneiss) and greywackes of the Nûkavsak Formation (Henderson \& Pulvertaft 1987). The contact between the Archaean basement and the Karrat Group was originally mapped as a series of faults, probably based on binocular observations from a boat in the 1960s, and from the black and white aerial photographs that were available at that time. The detail of our new oblique photographs clearly shows that this contact corresponds to a nonconformity with incised valleys into Archaean basement gneiss filled by Palaeoproterozoic siliciclastic rocks of the Karrat Group (Figs 2, 3).

The palaeotopography that is preserved below the Palaeoproterozoic sedimentary cover appears deeply excavated with highs and lows representing an ancient palaeodrainage system with a topographic relief of 300-400 m (Fig. 3). Qaarsukassak represents one of the domal structures described by Henderson \& Pulvertaft (1987), and the palaeotopography is accentuated by this fold structure. The south-eastern and north-western limbs of this wide upright anticline were visited and the basal unit was sampled (Fig. 2).

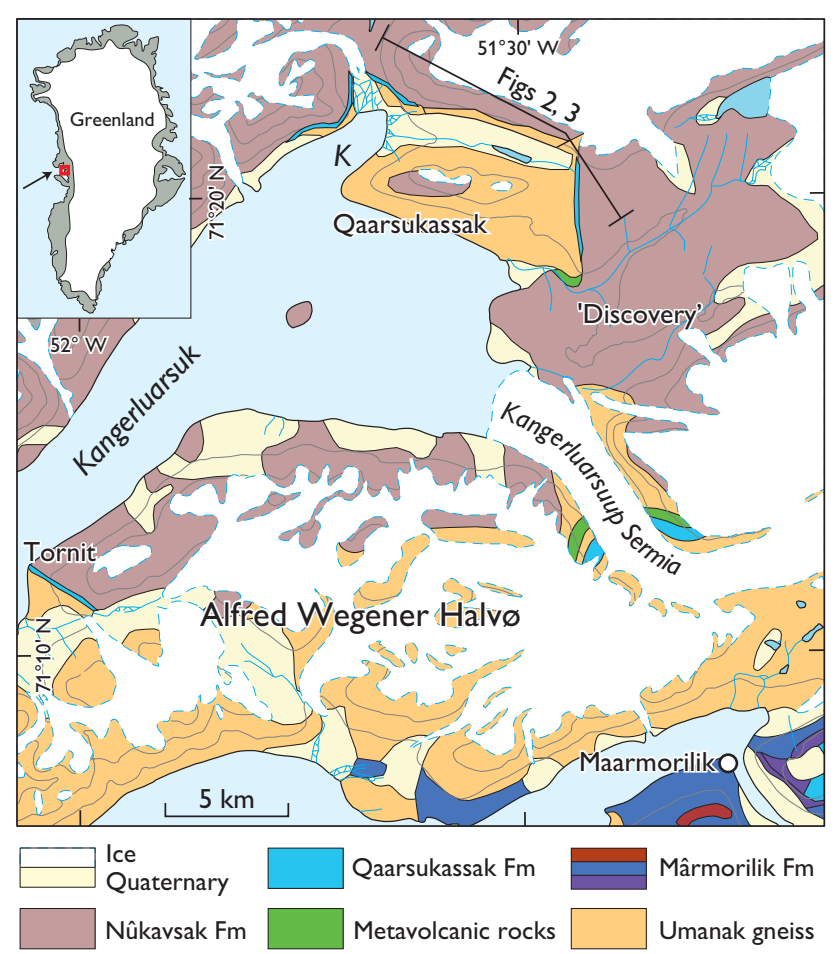

Fig. 1. Simplified geological map of the central Karrat Group area (modified from Escher \& Pulvertaft 1995). K: Kangerlussuakassak. 


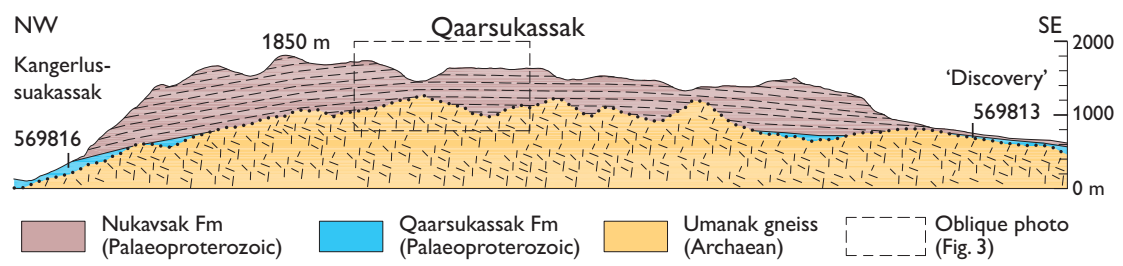

Fig. 2. Geological cross-section of Qaarsukasak showing the Palaeoproterozoic unconformity with the incised palaeovalleys into the Archaean Umanak gneiss infilled by the Qaarsukassaq Formation at the bottom and the Nûkavsak Formation on top. The locations along the cross-section of two analysed samples (Fig. 5) are also shown.

The overall geometry of the Archaean-Palaeoproterozoic unconformity displays important regional differences. In the Maarmorilik sector to the south the palaeosurface appears to be a peneplain covered by the basal quartzites of the Mârmorilik Formation described by Garde (1978); in the central Kangerluarsuk sector described here, it is represented by well-developed incisions filled with a new stratigraphic unit and local occurrences of lava flows. To the north of the studied area, in the Karrat Isfjord sector, the unconformity is represented by an undulated palaeosurface covered by thick metavolcanic rocks that were also noted by Henderson \& Pulvertaft (1987).

\section{Qaarsukassak Formation}

Here we describe a new stratigraphic unit in the Karrat Group, informally named the Qaarsukassak Formation, which occurs locally below the Nûkavsak Formation in the Kangerluarsuk fjord area (Fig. 1). This sequence was previously described at the so-called 'Discovery' showing by Coppard et al. (1992). The report describes a 30-66 m thick quartzite-carbonate succession with a mineralised zone occurring dominantly in calcite-bearing dolostone, and bounded by the Archaean basement gneiss and the Nûkavsak Formation. The measured section from the base to the inferred stratigraphic top (Fig. 4) reveals that its stratigraphic thickness prior to structural repetition is less than $20 \mathrm{~m}$.
The lower contact with the Archaean basement gneiss is a planar to undulating erosional surface that preserves a depositional contact. Laminated to massive quartzite fines upward into fine-grained metamorphosed sandstones and sandy mudstones, including calcite-cemented and graphitic quartzites (Unit 1). These siliciclastic rocks are overlain in sharp contact by light grey to white metacarbonate rocks with pods of massive tremolite and in some horizons, minor graphite (Unit 2). This is succeeded by another quartzite unit (Unit 3), followed by dark grey, laminated metacarbonate rocks with possible slump folds and minor tremolite veining (Unit 4). The overlying, rusty weathering metasedimentary rocks including graphitic, metamorphosed mudstones and siliciclastic rocks represent the ore zone (Unit 5). The upper contact of the Qaarsukassak Formation with the Nûkavsak Formation is not well-exposed. Also of note is a thin re-sedimented calcitic marble horizon within the basal part of the Nûkavsak Formation, which might be derived from contemporaneous erosion of the Qaarsukassak Formation.

All metacarbonate rocks in the Qaarsukassak Formation at the 'Discovery' section described here are calcitic. The Mârmorilik Formation, by contrast, contains both calcitic and dolomitic marble (Garde 1978). The primary occurrence of calcitic marble in the upper Mârmorilik Formation suggests possible correlation with the Qaarsukassak Formation. The presence of tremolite in some outcrops of

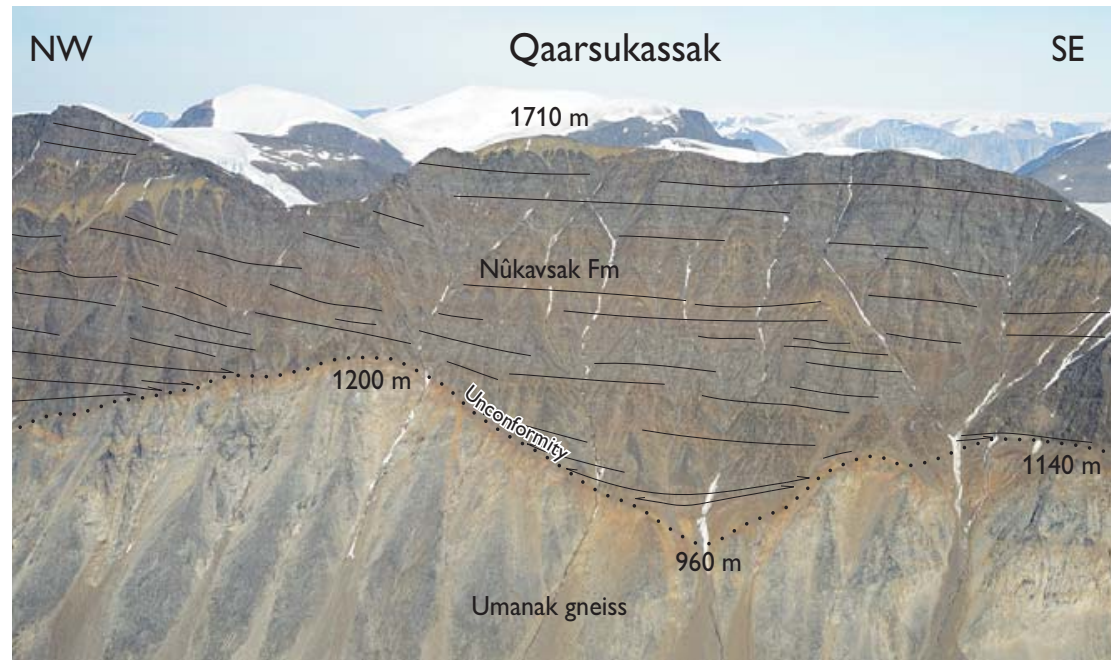

Fig. 3. The geometry of valleys and onlap of Palaeoproterozoic greywackes of the Nûkavsak Formation at Qaarsukassak, photographed from a helicopter. The difference between bottom and top of the palaeorelief is about 240 m. Position of image shown on Fig. 2. 


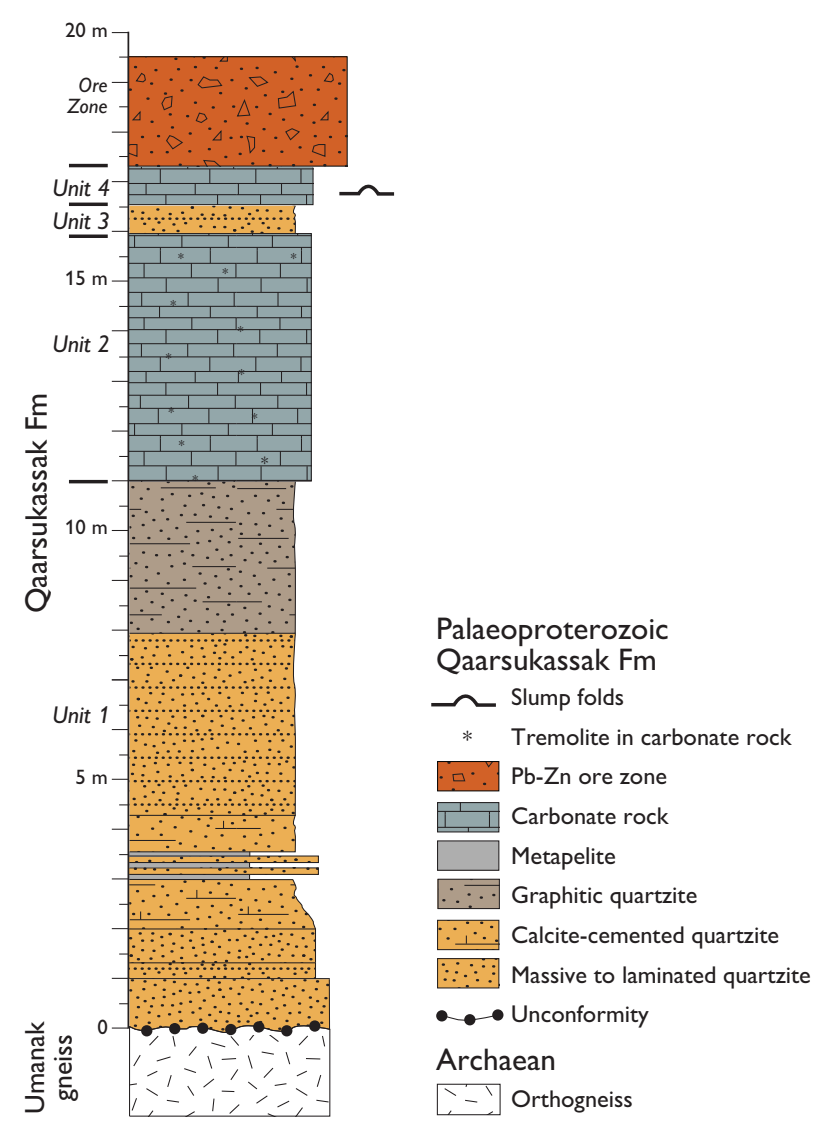

Fig. 4. Stratigraphic section of the Qaarsukassak Formation at the type locality of Qaarsukassak at head of Kangerluarsuk (Fig. 2 for location).

the Qaarsukassak Formation, though, suggests the former presence of dolomite or high-Mg calcite. Unit 1 of the Qaarsukassak Formation could represent a fluvial environment, but outcrops lack the sedimentary structures to confirm this. Instead, the Qaarsukassak Formation was likely deposited in a shallow marine environment. The Qaarsukassak Formation shows minor thickness variations along strike, suggesting that its deposition infilled pre-existing topographical lows in the Archaean basement gneiss. In addition to the main section in the 'Discovery' area, similar rocks also occur at two other localities, namely at Tornit on the south side of Kangerluarsuk and along Kangerluarsuup Sermia (Fig. 1), although exposures are not laterally continuous. At Tornit the orientation of the Qaarsukassak Formation is vertical and forms part of the overturned limb of the Kigarsima Nappe (Henderson \& Pulvertaft 1987). At this outcrop the formation occurs between a thin amphibolite unit and the Nûkavsak Formation as a $c .10 \mathrm{~m}$ thick section comprised of calcitic marble and rusty metasedimentary rocks, with quartzite, a possible quartz-pebble conglomerate and siliceous marble. The

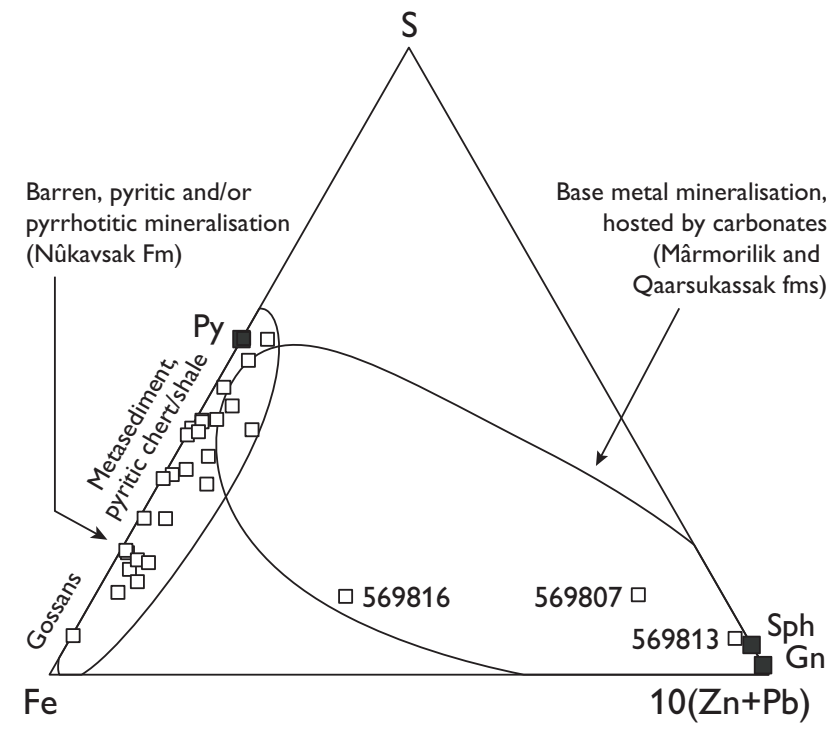

Fig. 5. $\mathrm{Fe}-\mathrm{S}-10(\mathrm{Zn}+\mathrm{Pb})$ ternary diagram with discriminant compositional areas of base-metal mineralisation hosted by carbonates of the Mârmorilik and Qaarsukassak formations (right) and the rusty-weathering zones hosted by the Nûkavsak Formation (left). Py: Pyrite. Gn: Galena. Sph: Sphalerite.

section might be repeated by folding and therefore only less than $10 \mathrm{~m}$ thick. At Kangerluarsuup Sermia an overturned $30-40 \mathrm{~m}$ section of dark grey, tremolite-bearing dolomitic marble with black layers of metamudstone occurs structurally below Archaean basement gneiss, which is thrust over the marble. The Qaarsukassak Formation extends to the north-west side of the section shown in Fig. 2 on the northwestern limb of the wide anticline at Kangerlussuakassak.

\section{Mineralisation}

Carbonate-hosted $\mathrm{Zn}-\mathrm{Pb}$ mineralisation is common in the calcitic marble of the upper Mârmorilik Formation and was exploited at the Black Angel mine between 1973 and 1990 (Thomassen 1991). Additionally, Coppard et al. (1992) identified intermittent stratabound $\mathrm{Zn}-\mathrm{Pb}$ mineralisation of the 'Discovery' and Kangerluarsuup Sermia occurrences, hosted within a carbonate and siliciclastic sequence. This sequence was considered to be the basal sequence of the Mârmorilik Formation by Coppard et al. (1992). Here, we allocate this succession to the Qaarsukassak Formation, since it is not in contact with the Mârmorilik Formation and the two units are separated by the basement topographic high. The recognition and understanding of the distribution of this formation are important as the formation controls the distribution of the regional $\mathrm{Zn}-\mathrm{Pb}$ mineralisation, which should be distinguished from rusty- 
weathering, pyritic or pyrrhotitic, but barren horizons located in the Nûkavsak Formation.

A ternary diagram (Fig. 5) discriminates the signatures of the base-metal mineralisation hosted by carbonate rocks of the Mârmorilik or Qaarsukassak formations, and of the rusty-weathering horizons hosted by the Nûkavsak Formation. The latter are dominated by pyrite or pyrrhotite and lack significant amounts of base metals (Fig. 5). Due to the effects of weathering, resulting in gossanous horizons, compositions of the sulphides in exposed rocks can depart from pyrite and become enriched in iron and depleted in sulphur. The former have variable amounts of iron sulphide, but can also have significant sphalerite or galena contents. The two samples closest to the metal corner were collected at the previously established 'Discovery' and 'South Lakes Glacier' occurrences, samples 569813 and 569807, respectively. A third sample (569816, Fig. 5) was collected c. 10 $\mathrm{km}$ to the north-west (Fig. 2) where mineralisation was not previously seen. Although the absolute base-metal content of this sample is not high, it is elevated relative to sulphur (akin to the tenor concept in nickel exploration). Its presence supports potential correlation with the Mârmorilik Formation and the proposed continuation of the Qaarsukassak Formation, hosting base-metal mineralisation, to the north-western limb of the wide anticline of the cross section shown in Fig. 2.

\section{Discussion and conclusion}

Henderson \& Pulvertaft (1987) proposed a Palaeoproterozoic structural high of Archaean basement gneiss exposed on Alfred Wegener Halvø, bounding the carbonate-dominated Mârmorilik basin to the south and separating it from the Qeqertarssuaq and Nûkavsak formations in the north. Our new observations show that such Archaean basement gneiss in the Kangerluarsuk area is heavily incised, and that Palaeoproterozoic palaeovalleys were filled in with siliciclastic and carbonate rocks of the Qaarsukassak Formation (new informal unit) that correlates well with the Mârmorilik Formation and is conformably overlain by the Nûkavsak Formation. Its intermediary, mixed siliciclasticcarbonate sedimentation could have been marginal marine and transitional into sedimentation of the turbiditic greywackes of the Nûkavsak Formation.
The palaeovalleys observed at Qaarsukassak seem to reflect an erosional event prior to the deposition of a sedimentary cycle represented by a carbonate-rich basin in the Maarmorilik area and an area rich in volcanic components in the north, separated by a continental shelf area. The erosion may have been related to a re-organisation of the basin structure, where uplift in some areas created the observed palaeotopography beneath the Nûkavsak Formation.

The observations in the Kangerluarsuk area described here, coupled with new observations from the Qeqertarssuaq Formation in the north which will be described elsewhere, may suggest that the Karrat Group comprises more than one sedimentary cycle separated by erosion and possibly deformation. An ongoing geochronological study of detrital zircon from different units within the Karrat Group is expected to yield new information about the depositional ages of its individual formations.

\section{Acknowledgments}

This work was carried out within the framework of an ongoing project financed by the Geological Survey of Denmark and Greenland (GEUS) and the Ministry of Mineral Resources of Greenland (MMR).

\section{References}

Coppard, J., Swatton, S. \& Harris, C.J. 1992: Karrat exclusive exploration licence. 1992 year-end report, 19 pp. Unpublished report, RTZ Mining and Exploration Limited (in archives of the Geological Survey of Denmark and Greenland, GEUS Report File 21297).

Escher, J.C. \& Pulvertaft, T.C.R. 1995: Geological map of Greenland, 1:2 500 000. Copenhagen: Geological Survey of Greenland.

Garde, A.A. 1978: The Lower Proterozoic Marmorilik Formation, east of Mârmorilik, West Greenland. Meddelelser om Grønland 200(3), $71 \mathrm{pp}$.

Grocott, J. \& Pulvertaft, T.C.R. 1990: The Early Proterozoic Rinkian belt of central West Greenland. In: Lewry, J.F. \& Stauffer, M.R. (eds) The Early Proterozoic Trans-Hudson Orogen of North America. Geological Association of Canada Special Paper 37, 443-463.

Henderson, G. \& Pulvertaft, T.C.R. 1967: The stratigraphy and structure of the Precambrian rocks of the Umanak area, West Greenland. Meddelelser fra Dansk Geologisk Forening 17, 1-22.

Henderson, G. \& Pulvertaft, T.C.R. 1987: Geological map of Greenland, 1:100 000. Mârmorilik 71 V.2 Syd, Nûgâtsiaq 71 V.2 Nord, Pangnertôq 72 V.2 Syd. Lithostratigraphy and structure of a Lower Proterozoic dome and nappe complex. Descriptive text. 72 pp. Copenhagen: Geological Survey of Greenland.

Thomassen, B. 1991: The Black Angel lead-zinc mine 1973-90. Rapport Grønlands Geologiske Undersøgelse 152, 46-50.

\footnotetext{
Authors' addresses

P.G. \& D.R., Geological Survey of Denmark and Greenland, Øster Voldgade 10,DK-1350 Copenhagen K, Denmark. Email: pgua@geus.dk C.A.P., Department of Geological Sciences, University of Saskatchewan, 114 Science Place, Saskatoon, SK S7N 5E2, Canada.
} 